\title{
Outcomes of Kidney Transplantation in Fabry Disease: A Meta-Analysis
}

\author{
Maria L. Gonzalez Suarez ${ }^{1,2}$, Charat Thongprayoon ${ }^{1, *}$, Panupong Hansrivijit ${ }^{3}{ }^{\oplus}$, Juan Medaura ${ }^{2}{ }^{\circledR}$, \\ Pradeep Vaitla ${ }^{2}{ }^{(}$, Michael A. Mao ${ }^{4} \oplus^{\circ}$, Tarun Bathini ${ }^{5}$, Boonphiphop Boonpheng ${ }^{6}$, Swetha R. Kanduri ${ }^{7}{ }^{(}$, \\ Karthik Kovvuru ${ }^{7}$, Arpita Basu ${ }^{8}{ }^{(1)}$ and Wisit Cheungpasitporn ${ }^{1, * \mathbb{B}}$
}

1 Division of Nephrology and Hypertension, Department of Medicine, Mayo Clinic, Rochester, MN 55905, USA; malourdes.gonzalez@gmail.com

2 Division of Nephrology, Department of Internal Medicine, University of Mississippi Medical Center, Jackson, MS 39216, USA; jmedaura@umc.edu (J.M.); pvaitla@umc.edu (P.V.)

3 Department of Internal Medicine, UPMC Pinnacle, Harrisburg, PA 17105, USA; hansrivijitp@upmc.edu

4 Division of Nephrology and Hypertension, Department of Medicine, Mayo Clinic, Jacksonville, FL 32224, USA; mao.michael@mayo.edu

5 Department of Internal Medicine, University of Arizona, Tucson, AZ 85721, USA; tarunjacobb@gmail.com

6 Department of Medicine, David Geffen School of Medicine, University of California,

Los Angeles, CA 90095, USA; boonpipop.b@gmail.com

7 Division of Nephrology, Ochsner Medical Center, New Orleans, LA 70121, USA; svetarani@gmail.com (S.R.K.); karthik.kovvuru@ochsner.org (K.K.)

8 Emory Transplant Center and Department of Medicine, Renal Division, Emory University School of Medicine, Atlanta, GA 30322, USA; arpita.basu@emory.edu

* Correspondence: charat.thongprayoon@gmail.com (C.T.); wcheungpasitporn@gmail.com (W.C.); Tel.: +1-507-266-1044 (C.T. \& W.C.)

check for updates

Citation: Suarez, M.L.G.; Thongprayoon, C.; Hansrivijit, P.; Medaura, J.; Vaitla, P.; Mao, M.A.; Bathini, T.; Boonpheng, B.; Kanduri, S.R.; Kovvuru, K.; et al. Outcomes of Kidney Transplantation in Fabry Disease: A Meta-Analysis. Diseases 2021, 9, 2. https: / dx.doi.org/ $10.3390 /$ diseases 9010002

Received: 13 November 2020 Accepted: 21 December 2020 Published: 23 December 2020

Publisher's Note: MDPI stays neutral with regard to jurisdictional claims in published maps and institutional affiliations.

Copyright: () 2020 by the authors. Licensee MDPI, Basel, Switzerland. This article is an open access article distributed under the terms and conditions of the Creative Commons Attribution (CC BY) license (https: / / creativecommons.org/ licenses/by/4.0/).

\begin{abstract}
Background: Fabry disease (FD) is a rare X-linked lysosomal storage disorder with progressive systemic deposition of globotriaosylceramide, leading to life-threatening cardiac, central nervous system, and kidney disease. Current therapy involves symptomatic medical management, enzyme replacement therapy (ERT), dialysis, kidney transplantation, and, more recently, gene therapy. The aim of this systematic review was to assess outcomes of kidney transplantation among patients with FD. Methods: A comprehensive literature review was conducted utilizing MEDLINE, EMBASE, and Cochrane Database, from inception through to 28 February 2020, to identify studies that evaluate outcomes of kidney transplantation including patient and allograft survival among kidney transplant patients with FD. Effect estimates from each study were extracted and combined using the random-effects generic inverse variance method of DerSimonian and Laird. Results: In total, 11 studies, including 424 kidney transplant recipients with FD, were enrolled. The post-transplant median follow-up time ranged from 3 to 11.5 years. Overall, the pooled estimated rates of all-cause graft failure, graft failure before death, and allograft rejection were $32.5 \%$ (95\%CI: $23.9 \%-42.5 \%$ ), 14.5\% (95\%CI: 8.4\%-23.7\%), and 20.2\% (95\%CI: $15.4 \%-25.9 \%)$, respectively. In the sensitivity analysis, limited only to the recent studies (year 2001 or newer when ERT became available), the pooled estimated rates of all-cause graft failure, graft failure before death, and allograft rejection were $28.1 \%$ (95\%CI: 20.5\%-37.3\%), 11.7\% (95\%CI: 8.4\%-16.0\%), and 20.2\% (95\%CI: 15.5\%-26.0\%), respectively. The pooled estimated rate of biopsy proven FD recurrence was 11.1\% (95\%CI: 3.6\%-29.4\%), respectively. There are no significant differences in the risks of all-cause graft failure $(p=0.10)$ or mortality (0.48) among recipients with vs. without FD. Conclusions: Despite possible FD recurrence after transplantation of $11.1 \%$, allograft and patient survival are comparable among kidney transplant recipients with vs. without FD.
\end{abstract}

Keywords: Fabry disease; kidney transplant; kidney transplantation; meta-analysis; systematic review 


\section{Introduction}

Fabry disease (FD) is a rare, progressive, multisystemic, and X-linked inherited lysosomal disorder, caused by genetic variations in GLA (HUGO Gene Nomenclature Committee ID: 4296; Gene Entrez: 2717; NCBI reference sequence: NM_000169.2), which encodes $\alpha$ galactosidase ( $\alpha$-Gal, Enzyme Commission number: EC 3.2.1.22; UniProt ID: P06280) [1,2]. Studies have recently identified a variety of variants underlying the phenotypic heterogeneity of this genetic disorder [3-19]. The GLA variants can lead to the deficiency of the lysosomal enzyme $\alpha$-galactosidase A ( $\alpha$-gal A) [20-27]. This enzyme is active in glycosphingolipid catabolism and accumulation of neutral glycosphingolipids, namely, globotriaosylceramide (Gb3), which is the hallmark pathogenesis leading to clinical syndromes $[20,28]$. The incidence of FD in the general population ranges from $~ 1: 40,000$ to 1:60,000 among male patients [29-31]. The clinical presentations of Fabry syndrome include cardiomyopathy, cerebrovascular disease, and renal failure [32,33]. Renal involvement in FD has been recognized as a cardinal feature which pertains specific pathological characteristics and prognosis [34].

Fabry nephropathy is one of the causes of chronic kidney disease, similar to diabetic kidney disease, which could progress to end-stage kidney disease in the fifth decade of life [34]. It has been reported that the natural history of Fabry nephropathy may evolve in three clinical phases [35]. The first phase is glomerular hyperfiltration which usually has onset in childhood or adolescence. The second phase involves proteinuria, lipiduria, or Maltese cross crystals. In Branton et al., proteinuria is the most common renal manifestation at the mean age of 34 years [34]. Lastly, the final phase is characterized by several renal diseases and progression to end-stage kidney disease. Patients may also exhibit vascular, cardiac and cerebrovascular involvement at this stage as well. Other uncommon features of FD include, but are not limited to, nephrogenic diabetes insipidus and Fanconi syndrome. Current therapies involve symptomatic medical management, enzyme replacement therapy (ERT), dialysis, and kidney transplantation [35].

The role of kidney transplantation in FD has been subjected to certain controversies. Some evidence suggests that kidney transplant increases serum $\alpha$-gal A [36-38] and urine $\alpha$-gal A [39,40]. Graft failure secondary to substrate deposition has also been suggested [41]. However, current evidence to date on the outcomes of kidney transplantation in FD is limited due to the small sample size in each individual study making it difficult to apply to clinical practice. Thus, this systematic review and meta-analysis was conducted to describe the clinical outcomes among the pooled sample size from all available studies.

\section{Materials and Methods}

\subsection{Search Strategies}

A comprehensive search of several databases, from each database's inception to February 28, 2020, was conducted. The databases included OVID MEDLINE (1946 to February 2020), EMBASE (1988 to February 2020), and the Cochrane Database of Systematic Reviews (database inception to February 2020). The systematic literature review was conducted independently by two investigators (M.L.G.S. and C.T.) using the search strategy that consolidated the terms of ("kidney transplantation" OR "kidney graft" OR "kidney graft rejection" OR (renal AND transplantation)) AND ("fabry disease" OR "lysosomal storage disease"). The actual strategy listing all search terms used is available in the online Supplementary Data. There were no restrictions on language, sample size, or study duration. This study was conducted by the Preferred Reporting Items for Systematic Reviews and Meta-Analysis (PRISMA) statement [42].

\subsection{Study Selection}

Eligible studies must be clinical trials, observational studies (cohort, case-control, or cross-sectional studies) that reported incidence and/or outcomes of kidney transplantation among patients with FD. Retrieved articles were individually reviewed for eligibility by two investigators (M.L.G.S. and C.T.). Discrepancies were addressed and resolved 
by a third investigator (W.C.). Inclusion was not limited by language, age, sample size, or study duration.

\subsection{Data Extraction}

The following data were extracted: first author name, year of publication, number of patients, duration of follow-up, diagnosis of FD, mean age, sex, incidence of FD recurrence, patient survival, graft survival, and allograft rejection. The primary outcome was allograft survival.

\subsection{Data Synthesis and Statistical Analysis}

We calculated pooled estimated rates of FD recurrence, patient survival, graft survival, and allograft rejection among kidney transplant patients with FD. A random-effects model was used due to the expected clinical heterogeneity in the included populations [43]. All pooled estimates were shown with $95 \%$ confidence intervals (CIs). Heterogeneity among effect sizes estimated by individual studies was described with the $\mathrm{I}^{2}$ statistic and the chi-square test. A value of I2 of $0 \%$ to $25 \%$ represents insignificant heterogeneity, $26 \%$ to $50 \%$ low heterogeneity, $51 \%$ to $75 \%$ moderate heterogeneity, and 76 to $100 \%$ high heterogeneity [44].

Publication bias was evaluated using the Egger test [45]. A $p$-value of less than 0.05 indicates the presence of publication bias. The meta-analysis was performed by the Comprehensive Meta-Analysis 3.3 software (Biostat Inc., Englewood, NJ, USA). The data for this metaanalysis are publicly available through the Open Science Framework (URL: osf.io/amrxq/).

\section{Results}

In total, 11 studies, including 424 kidney transplant recipients with FD, were enrolled (Figure 1 and Table 1) [46-56]. The post-transplant median follow-up time ranged from 3 to 11.5 years.

Overall, the pooled estimated rates of all-cause graft failure, graft failure before death, and allograft rejection were 32.5\% (95\%CI: $\left.23.9 \%-42.5 \%, \mathrm{I}^{2}=50 \%\right), 14.5 \%(95 \% \mathrm{CI}$ : $8.4 \%-23.7 \%$ ), and $20.2 \%$ (95\%CI: $15.4 \%-25.9 \%$ ), respectively (Figure 2). From a sensitivity analysis limited only to the recent studies (year 2001 or newer when ERT became available) (Table 1), the pooled estimated rates of all-cause graft failure, graft failure before death, and allograft rejection were $28.1 \%$ (95\%CI: $20.5 \%-37.3 \%$ ), $11.7 \%$ (95\%CI: $8.4 \%-16.0 \%$ ), and $20.2 \%$ (95\%CI: $15.5 \%-26.0 \%)$, respectively.

The pooled estimated rate of biopsy proven FD recurrence was $11.1 \%$ (95\% CI: 3.6\%$29.4 \%)$, respectively. There are no significant differences in the risks of all-cause graft failure $(P=0.10)$ (Figure 3$)$ or mortality (0.48) among recipients with vs. without FD. The Egger's regression demonstrated no significant publication bias for all analyses $(p>0.05)$. 


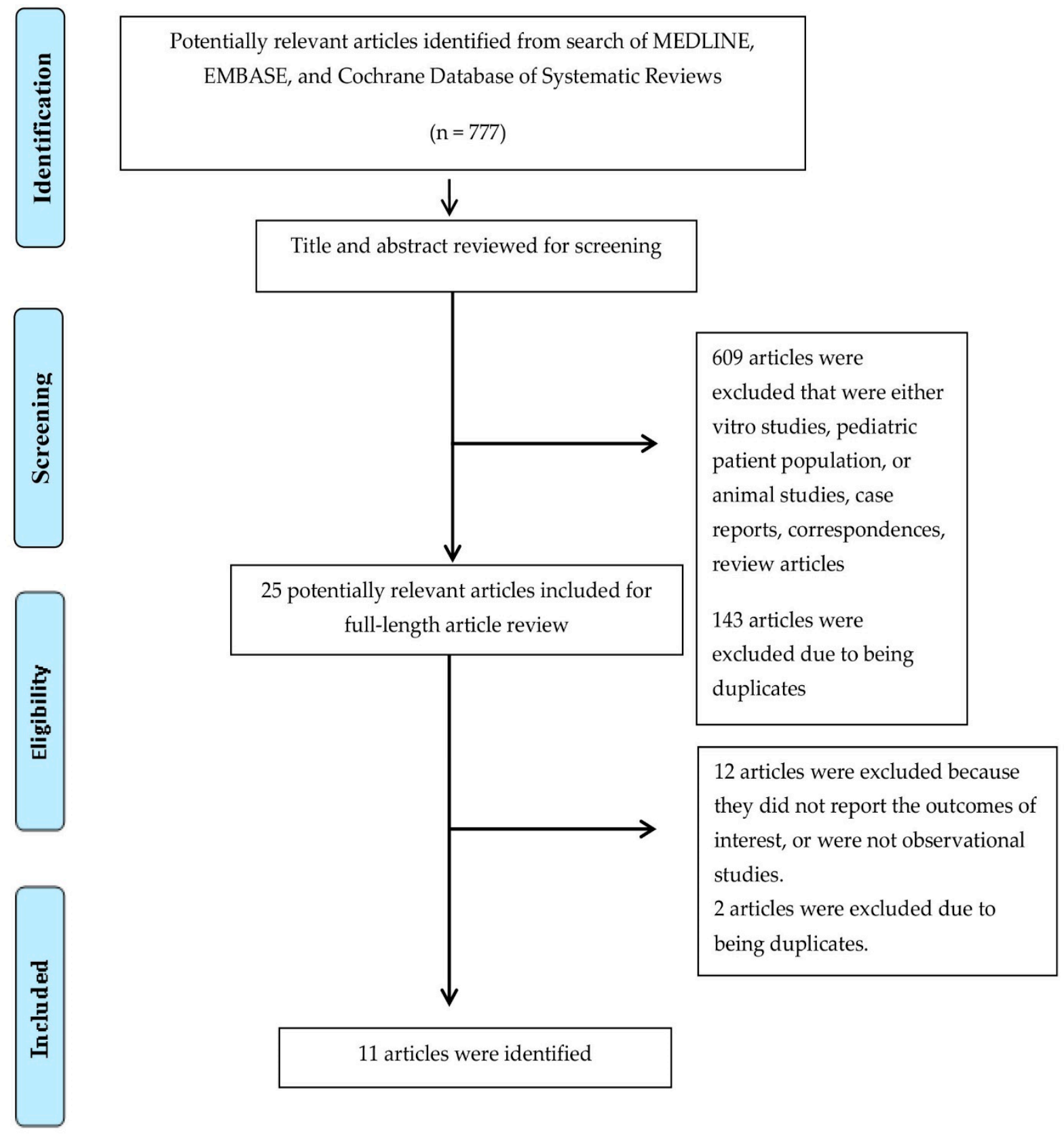

Figure 1. Preferred Reporting Items for Systematic Reviews and Meta-Analysis (PRISMA) flow diagram for study selection. 
Table 1. Characteristics of included studies in systematic review [46-56].

\begin{tabular}{|c|c|c|c|c|c|c|c|c|c|c|c|c|c|}
\hline Study & Year & $\mathbf{N}$ & Male Sex & $\begin{array}{c}\text { Mean Age } \\
\text { at } \\
\text { Diagnosis }\end{array}$ & $\begin{array}{l}\text { Mean Age } \\
\text { at } \\
\text { Transplant }\end{array}$ & $\begin{array}{l}\text { Enzyme Re- } \\
\text { placement } \\
\text { Therapy }\end{array}$ & $\begin{array}{c}\text { Age at Enzyme } \\
\text { Replacement } \\
\text { Therapy }\end{array}$ & $\begin{array}{l}\text { Follow-Up } \\
\text { Time }\end{array}$ & $\begin{array}{l}\text { Patient } \\
\text { Death }\end{array}$ & $\begin{array}{c}\text { Graft } \\
\text { Failure } \\
\text { Before } \\
\text { Death }\end{array}$ & $\begin{array}{l}\text { All-Cause } \\
\text { Graft } \\
\text { Failure }\end{array}$ & $\begin{array}{c}\text { Graft } \\
\text { Rejection }\end{array}$ & $\begin{array}{l}\text { Recurrence of } \\
\text { FD in Kidney } \\
\text { Allograft }\end{array}$ \\
\hline Barnes et al. [46] & 1975 & 9 & $8 / 9(89 \%)$ & N/A & 41 years & $0 / 0(0 \%)$ & N/A & N/A & $6(67 \%)$ & $0(0 \%)$ & $6(67 \%)$ & N/A & $\mathrm{N} / \mathrm{A}$ \\
\hline Donati et al. [47] & 1987 & 8 & $8 / 8(100 \%)$ & 29.9 years & 36.8 years & $0 / 8(0 \%)$ & N/A & 3.6 years & 0 & $5(63 \%)$ & $5(63 \%)$ & $\mathrm{N} / \mathrm{A}$ & $\mathrm{N} / \mathrm{A}$ \\
\hline $\begin{array}{c}\text { Tsakiris et al. } \\
\text { [48] }\end{array}$ & 1996 & 33 & $73 / 83(88 \%)$ & N/A & - & $0 / 0(0 \%)$ & N/A & 3 years & $5(15 \%)$ & $\mathrm{N} / \mathrm{A}$ & $9(27 \%)$ & N/A & $\mathrm{N} / \mathrm{A}$ \\
\hline $\begin{array}{l}\text { Mazzarella et al. } \\
\text { [49] }\end{array}$ & 1997 & 2 & $2 / 2(100 \%)$ & $\mathrm{N} / \mathrm{A}$ & 32 years & $0 / 0(0 \%)$ & $\mathrm{N} / \mathrm{A}$ & 3.8 years & $0(0 \%)$ & $0(0 \%)$ & $0(0)$ & $0(0 \%)$ & $\mathrm{N} / \mathrm{A}$ \\
\hline $\begin{array}{c}\text { Inderbitzin et al. } \\
{[50]}\end{array}$ & 2005 & 10 & $\begin{array}{l}10 / 10 \\
(100 \%)\end{array}$ & 26 years & 36 years & $1 / 10(10 \%)$ & N/A & 10.2 years & $4(40 \%)$ & $1(10 \%)$ & $5(50 \%)$ & $1(10 \%)$ & $\begin{array}{c}0 \text {-clinically } \\
1 \text {-in autopsy } \\
\text { biopsy }\end{array}$ \\
\hline $\begin{array}{c}\text { Mignani et al. } \\
\text { [51] }\end{array}$ & 2008 & 17 & $16 / 17(94 \%)$ & 37.1 years & 39.8 years & $\begin{array}{c}17 / 17 \\
(100 \%) \\
\end{array}$ & 44.6 years & 6 years & $0(0 \%)$ & $2(12 \%)$ & $2(12 \%)$ & N/A & $\mathrm{N} / \mathrm{A}$ \\
\hline $\begin{array}{c}\text { Cybulla et al. } \\
\text { [52] }\end{array}$ & 2009 & 36 & $34 / 36(94 \%)$ & 31.1 years & 37.6 years & $24 / 36(67 \%)$ & N/A & 7.7 years & $4(11 \%)$ & $3(8 \%)$ & N/A & N/A & N/A \\
\hline Shah et al. [53] & 2009 & $\begin{array}{c}\text { FD } \\
197 \\
\text { Control } \\
1970\end{array}$ & $\begin{array}{c}177 / 197 \\
(90 \%)\end{array}$ & $\mathrm{N} / \mathrm{A}$ & $\mathrm{N} / \mathrm{A}$ & $\mathrm{N} / \mathrm{A}$ & N/A & 5 years & $\begin{array}{c}\text { FD } \\
37(19 \%)\end{array}$ & $\begin{array}{c}\text { FD } \\
24(12 \%)\end{array}$ & $\begin{array}{c}\text { FD } \\
51(26 \%)\end{array}$ & $\begin{array}{c}\text { FD } \\
41(21 \%) \\
\text { Control } \\
528(27 \%)\end{array}$ & N/A \\
\hline Ojo et al. [54] & 2000 & $\begin{array}{c}\text { FD } \\
93 \\
\text { Control } \\
186\end{array}$ & 83/93 (89) & N/A & 40 years & $\mathrm{N} / \mathrm{A}$ & N/A & 5 years & $\begin{array}{c}\text { FD } \\
16(17 \%) \\
\text { Control } \\
34(18 \%)\end{array}$ & $\mathrm{N} / \mathrm{A}$ & $\begin{array}{c}\text { FD } \\
22(24 \%) \\
\text { Control } \\
62(33 \%)\end{array}$ & N/A & $\mathrm{N} / \mathrm{A}$ \\
\hline $\begin{array}{c}\text { Pineda- } \\
\text { Galindo et al. } \\
{[55]}\end{array}$ & 2016 & 2 & $2 / 2(100 \%)$ & $\mathrm{N} / \mathrm{A}$ & N/A & $2 / 2(100 \%)$ & N/A & 6 years & $0(0 \%)$ & $0(0 \%)$ & $0(0 \%)$ & N/A & N/A \\
\hline $\begin{array}{c}\text { Ersozlu et al. } \\
{[56]}\end{array}$ & 2018 & $\begin{array}{c}\text { FD } \\
17 \\
\text { Control } \\
17\end{array}$ & $15 / 17(88 \%)$ & 34 years & 39.5 years & $14 / 17(82 \%)$ & 40.3 years & 11.5 years & $\begin{array}{c}\text { FD } \\
7(41 \%) \\
\text { Control } \\
2(12 \%)\end{array}$ & $\begin{array}{c}\text { FD } \\
2(12 \%) \\
\text { Control } \\
9(53 \%)\end{array}$ & $\begin{array}{c}\text { FD } \\
8(47 \%) \\
\text { Control } \\
9(53 \%)\end{array}$ & $\begin{array}{c}\text { FD } \\
3(18 \%)\end{array}$ & $\begin{array}{c}\text { FD } \\
2(12 \%)-\text { kidney } \\
\text { biopsy }\end{array}$ \\
\hline
\end{tabular}




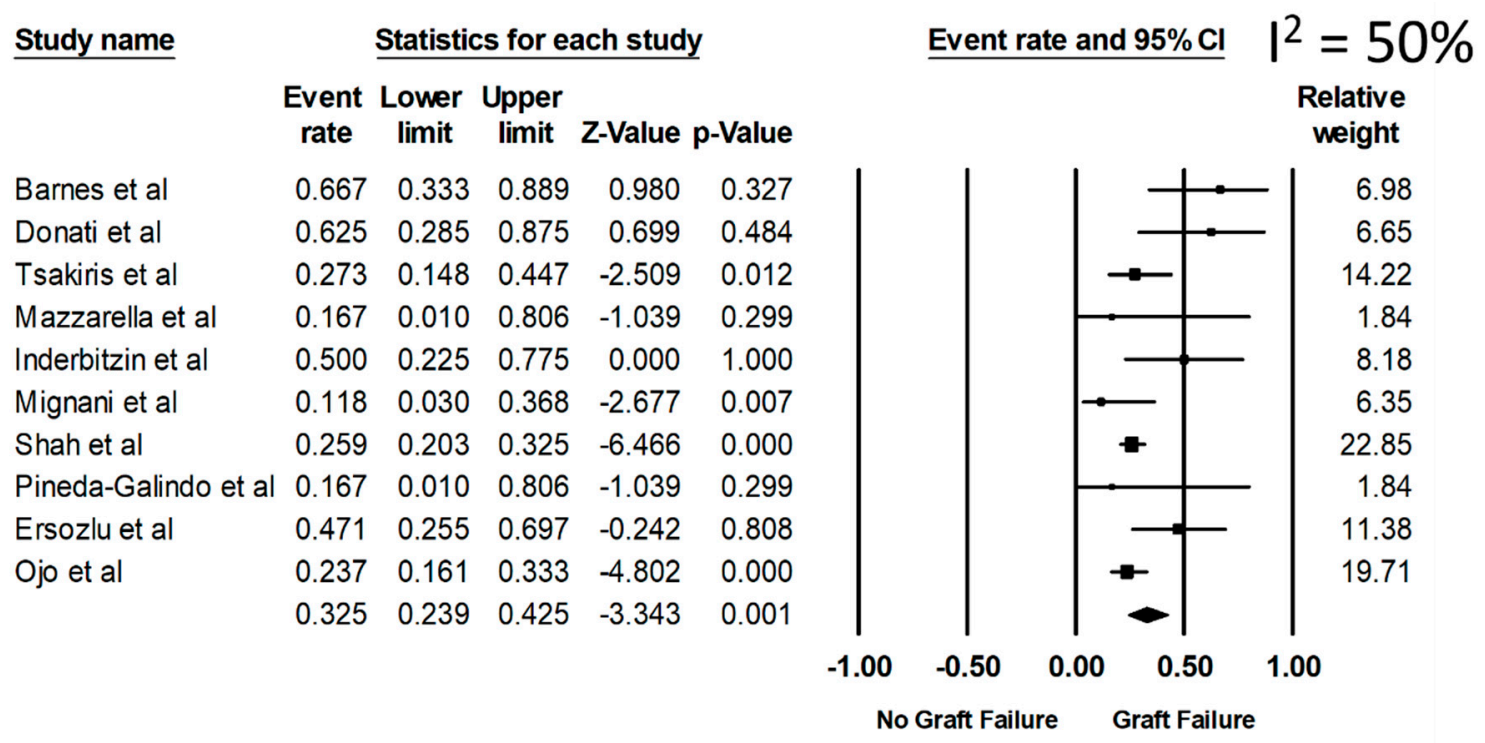

Figure 2. Rate of all-cause graft failure among kidney transplant patients with FD.

\begin{tabular}{lllllll}
\multicolumn{1}{c}{ Study name } & & \multicolumn{5}{c}{ Statistics for each study } \\
\cline { 3 - 6 } $\begin{array}{c}\text { Odds } \\
\text { ratio }\end{array}$ & $\begin{array}{l}\text { Lower Upper } \\
\text { limit }\end{array}$ & limit & Z-Value p-Value \\
Ersozlu et al & 0.790 & 0.205 & 3.038 & -0.343 & 0.732 \\
Ojo et al & 0.620 & 0.351 & 1.093 & -1.654 & 0.098 \\
& 0.643 & 0.381 & 1.084 & -1.657 & 0.098
\end{tabular}

\section{Odds ratio and $95 \% \mathrm{Cl}$}

Odds Lower Upper
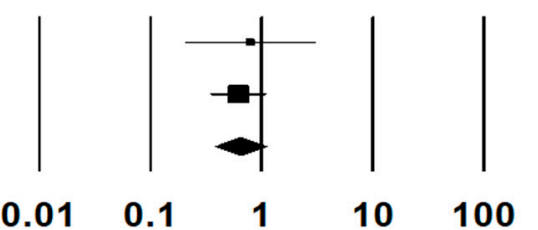

Figure 3. Risk of all-cause graft failure among kidney transplant patients with FD.

\section{Discussion}

Here, we reported that the pooled estimated rates of all-cause graft failure, graft failure before death, and allograft rejection were $32.5 \%, 14.5 \%$, and $20.2 \%$, respectively, with a median follow-up time ranging from 3 to 11.5 years. We also found no significant difference in the risk of all-cause graft failure or the mortality among recipients with and without FD. However, the incidence of graft failure in FD patients is overtly higher than those with diabetes. One retrospective cohort study showed that the incidence of graft failure in diabetic patients was $6.7 \%$ compared to $2.8 \%$ in nondiabetic patients [57]. Overall, our data indicated that kidney transplantation due to FD is safe and should be considered in patients with end-stage kidney disease due to Fabry nephropathy.

In 1975, the American College of Surgeons and the National Institute of Health Renal Transplant Registry reviewed the outcomes of kidney transplantation in several congenital metabolic diseases. The good outcomes following kidney transplantation were highlighted in patients with Alport syndrome, amyloidosis, cystinosis, and others with the exception of FD and oxalosis. The graft survival after one year was only $33 \%$ without reported evidence of relapses [46]. The 5-year survival rate among kidney transplant recipients with FD was up to $26 \%$ with a high incidence of sepsis [58]. Because of these discouraging early data, kidney transplants in FD patients were not recommended.

We also demonstrated that the incidence of all-cause graft failure $(28.1 \%)$ and deathcensored graft failure (11.7\%) have declined over time, especially in studies published after 2001 or when enzyme replacement therapy (ERT) became available, whereas the incidence 
of allograft rejection remained unchanged (20.2\%). Earlier studies among Fabry patients after kidney transplantation reported a rise in galactosidase enzyme levels secondary to lysosomal enzyme release from transplanted organ [59-61]. However, it was reported to be from increased $\alpha-\mathrm{N}$-acetylgalactosaminidase ( $\alpha-\mathrm{Gal} \mathrm{B}$ ) activity, a similar enzyme to $\alpha$-Gal A $[60,61]$. Subsequently, the effect was found to be transient and did not effectively reduce Gb3 levels. Hence, further ERT is warranted after kidney transplantation $[62,63]$. Cybulla et al. [52] analyzed a cohort of kidney transplant patients with FD and evaluated the efficacy and safety of ERT (Agalsidase alfa). Among kidney transplant patients receiving ERT, slight increases in serum creatinine as compared to baseline were reported after 2 years. However, proteinuria remained stable. All patients tolerated ERT well with minimal adverse effects. On comparing extra renal effects, the left ventricular mass was greater in untreated patients as opposed to patients on ERT. Similar results were reported in a pilot study from Mignani and colleagues among kidney transplant recipients. Stable renal functions, decreased plasma Gb3 levels, decreased left ventricular mass and improved cardiac contractility were reported among transplanted patients on ERT [64].

One of the challenges with ERT is the development of ERT antibodies, as this complicates treatment among Fabry disease patients $[65,66]$. In patients after kidney transplant, there appears to be a protective role of immunosuppressive medications on emergence of ERT antibodies. This effect was illustrated by Lenders et al. who evaluated the impact of immunosuppressive medications after kidney transplantation in patients with Fabry nephropathy. Patients who were started on ERT post-kidney transplant did not develop new ERT antibodies in long-term follow up. Concurrently, patients who developed ERT antibodies before transplant had temporary suppression of antibodies post-transplant, indicating the potential protective role of immunosuppression after kidney transplantation [67].

The long-term outcome of kidney transplantation in FD patients was reintroduced after several newer studies reported promising data on graft survival and patient survival. The European Renal Association Registry reported $72 \%$ graft survival and $84 \%$ patient survival after 3-year follow-up [48]. Similarly, the U.S. Renal Data System has reported a 5 -year graft survival and patient survival of $76 \%$ and $83 \%$, respectively [54]. The incidence of allograft rejection is identical in patients with vs. without FD, which might indicate that ERT does not affect the rejection rate. In other kidney diseases, rejection is usually caused by under-immunosuppression which could become problematic in immune-mediated diseases where frequent adjustment of immunosuppressive regimen is warranted. Altogether, we showed that kidney transplant in FD patients is not different from other kidney diseases with respect to transplant profile.

Here, we reported the incidence of FD recurrence in kidney transplant patients for the first time (11.1\%) with a median follow-up duration ranging from 3 to 11.5 years. Since 1972, the data on recurrent FD post-kidney transplant have been scarcely reported due to small sample sizes. Most studies were retrospective and had quite different biopsy and transplant timings. However, recurrent FD was determined by histological features from the kidney biopsy [54]. Some possible mechanisms leading to recurrent Fabry nephropathy were proposed. New deposition of $\mathrm{Gb} 3$ can occur along the endothelial cells within renal tubular cells and podocytes. Moreover, migration of activated macrophage into the graft tissue has also been proposed [26]. More research on the pathogenesis of recurrent Fabry nephropathy in kidney allografts is of great interest as not many studies are currently available.

Our study is the first systematic review to report the allograft outcomes of Fabry nephropathy. However, some limitations may be imposed. First, given the observational design in nature, the reported findings may be subjected to selection bias. Some included studies were published before ERT was established, and it is well known that this treatment had a profound impact on the outcome of the disease. Thus, we performed additionally analysis including only the recent studies (year 2001 or newer when ERT became available) and demonstrated the pooled estimated rates of all-cause graft failure, graft failure before death, and allograft rejection of $28.1 \%, 11.7 \%$, and $20.2 \%$, respectively. Second, the transplant outcomes of Fabry nephropathy were not directly compared to other diagnoses. 
Thus, the clinical applicability of our findings should be adopted with caution. Third, although sample sizes were pooled, the total number of subjects remained small. Fourth, the majority of FD patients included in our systematic review were males and data on patients' comorbidities were limited. Thus, future studies are needed to assess outcomes of kidney transplantation among female patients with FD.

\section{Conclusions}

In summary, the allograft and patient outcomes in patients with FD are comparable to other kidney diseases with a recurrence rate of $11 \%$ during a follow-duration of up to 11.5 years.

Supplementary Materials: The following are available online at https:/ /www.mdpi.com/2079-972 $1 / 9 / 1 / 2 /$ s1.

Author Contributions: M.L.G.S., C.T., P.H., J.M., P.V., M.A.M., T.B., B.B., S.R.K., K.K., A.B., and W.C. gave final approval and agreed to be accountable for all aspects of work ensuring integrity and accuracy. All authors have read and agreed to the published version of the manuscript.

Funding: This research received no external funding.

Conflicts of Interest: The authors have declared that no competing interests exist.

\section{References}

1. Germain, D.P. Fabry disease. Orphanet J. Rare Dis. 2010, 5, 30. [CrossRef] [PubMed]

2. Germain, D.P.; Oliveira, J.P.; Bichet, D.G.; Yoo, H.W.; Hopkin, R.J.; Lemay, R.; Politei, J.; Wanner, C.; Wilcox, W.R.; Warnock, D.G. Use of a rare disease registry for establishing phenotypic classification of previously unassigned GLA variants: A consensus classification system by a multispecialty Fabry disease genotype-phenotype workgroup. J. Med. Genet. 2020, 57, 542-551. [CrossRef] [PubMed]

3. Ashley, G.A.; Shabbeer, J.; Yasuda, M.; Eng, C.M.; Desnick, R.J. Fabry disease: Twenty novel alpha-galactosidase A mutations causing the classical phenotype. J. Hum. Genet. 2001, 46, 192-196. [CrossRef] [PubMed]

4. Ashton-Prolla, P.; Tong, B.; Shabbeer, J.; Astrin, K.H.; Eng, C.M.; Desnick, R.J. Fabry disease: Twenty-two novel mutations in the alpha-galactosidase A gene and genotype/phenotype correlations in severely and mildly affected hemizygotes and heterozygotes. J. Investig. Med. 2000, 48, 227-235. [PubMed]

5. Davies, J.P.; Eng, C.M.; Hill, J.A.; Malcolm, S.; MacDermot, K.; Winchester, B.; Desnick, R.J. Fabry disease: Fourteen alphagalactosidase A mutations in unrelated families from the United Kingdom and other European countries. Eur. J. Hum. Genet. 1996, 4, 219-224. [CrossRef] [PubMed]

6. Eng, C.M.; Ashley, G.A.; Burgert, T.S.; Enriquez, A.L.; D’Souza, M.; Desnick, R.J. Fabry disease: Thirty-five mutations in the alpha-galactosidase A gene in patients with classic and variant phenotypes. Mol. Med. 1997, 3, 174-182. [CrossRef]

7. $\quad$ Eng, C.M.; Niehaus, D.J.; Enriquez, A.L.; Burgert, T.S.; Ludman, M.D.; Desnick, R.J. Fabry disease: Twenty-three mutations including sense and antisense $\mathrm{CpG}$ alterations and identification of a deletional hot-spot in the alpha-galactosidase A gene. Hum. Mol. Genet. 1994, 3, 1795-1799. [CrossRef]

8. Germain, D.; Biasotto, M.; Tosi, M.; Meo, T.; Kahn, A.; Poenaru, L. Fluorescence-assisted mismatch analysis (FAMA) for exhaustive screening of the alpha-galactosidase A gene and detection of carriers in Fabry disease. Hum. Genet. 1996, 98, 719-726. [CrossRef]

9. Germain, D.P. A new phenotype of Fabry disease with intermediate severity between the classical form and the cardiac variant. Contrib. Nephrol. 2001, 234-240. [CrossRef]

10. Germain, D.P.; Poenaru, L. Fabry disease: Identification of novel alpha-galactosidase A mutations and molecular carrier detection by use of fluorescent chemical cleavage of mismatches. Biochem. Biophys. Res. Commun. 1999, 257, 708-713. [CrossRef]

11. Germain, D.P.; Shabbeer, J.; Cotigny, S.; Desnick, R.J. Fabry disease: Twenty novel alpha-galactosidase A mutations and genotype-phenotype correlations in classical and variant phenotypes. Mol. Med. 2002, 8, 306-312. [CrossRef] [PubMed]

12. Ishii, S.; Kase, R.; Sakuraba, H.; Suzuki, Y. Characterization of a mutant alpha-galactosidase gene product for the late-onset cardiac form of Fabry disease. Biochem. Biophys. Res. Commun. 1993, 197, 1585-1589. [CrossRef] [PubMed]

13. Ishii, S.; Nakao, S.; Minamikawa-Tachino, R.; Desnick, R.J.; Fan, J.Q. Alternative splicing in the alpha-galactosidase A gene: Increased exon inclusion results in the Fabry cardiac phenotype. Am. J. Hum. Genet. 2002, 70, 994-1002. [CrossRef] [PubMed]

14. Ishii, S.; Sakuraba, H.; Suzuki, Y. Point mutations in the upstream region of the alpha-galactosidase A gene exon 6 in an atypical variant of Fabry disease. Hum. Genet. 1992, 89, 29-32. [CrossRef] [PubMed]

15. Ploos van Amstel, J.K.; Jansen, R.P.; de Jong, J.G.; Hamel, B.C.; Wevers, R.A. Six novel mutations in the alpha-galactosidase A gene in families with Fabry disease. Hum. Mol. Genet. 1994, 3, 503-505. [CrossRef]

16. Sakuraba, H.; Oshima, A.; Fukuhara, Y.; Shimmoto, M.; Nagao, Y.; Bishop, D.F.; Desnick, R.J.; Suzuki, Y. Identification of point mutations in the alpha-galactosidase A gene in classical and atypical hemizygotes with Fabry disease. Am. J. Hum. Genet. 1990, $47,784-789$. 
17. Shabbeer, J.; Yasuda, M.; Luca, E.; Desnick, R.J. Fabry disease: 45 novel mutations in the alpha-galactosidase A gene causing the classical phenotype. Mol. Genet. Metab. 2002, 76, 23-30. [CrossRef]

18. Shabbeer, J.; Yasuda, M.; Benson, S.D.; Desnick, R.J. Fabry disease: Identification of 50 novel alpha-galactosidase A mutations causing the classic phenotype and three-dimensional structural analysis of 29 missense mutations. Hum. Genom. 2006, 2, 297-309. [CrossRef]

19. Topaloglu, A.K.; Ashley, G.A.; Tong, B.; Shabbeer, J.; Astrin, K.H.; Eng, C.M.; Desnick, R.J. Twenty novel mutations in the alpha-galactosidase A gene causing Fabry disease. Mol. Med. 1999, 5, 806-811. [CrossRef]

20. Desnick, R.J.; Brady, R.; Barranger, J.; Collins, A.J.; Germain, D.P.; Goldman, M.; Grabowski, G.; Packman, S.; Wilcox, W.R. Fabry disease, an under-recognized multisystemic disorder: Expert recommendations for diagnosis, management, and enzyme replacement therapy. Ann. Intern. Med. 2003, 138, 338-346. [CrossRef]

21. Shin, S.H.; Park, M.H.; Byeon, J.J.; Lee, B.I.; Park, Y.; Ko, A.R.; Seong, M.R.; Lee, S.; Kim, M.R.; Seo, J.; et al. A Liquid Chromatography-Quadrupole-Time-of-Flight Mass Spectrometric Assay for the Quantification of Fabry Disease Biomarker Globotriaosylceramide (GB3) in Fabry Model Mouse. Pharmaceutics 2018, 10, 69. [CrossRef] [PubMed]

22. Esposito, R.; Russo, C.; Santoro, C.; Cocozza, S.; Riccio, E.; Sorrentino, R.; Pontillo, G.; Luciano, F.; Imbriaco, M.; Brunetti, A.; et al. Association between Left Atrial Deformation and Brain Involvement in Patients with Anderson-Fabry Disease at Diagnosis. J. Clin. Med. 2020, 9, 2741. [CrossRef] [PubMed]

23. Levstek, T.; Vujkovac, B.; Trebusak Podkrajsek, K. Biomarkers of Fabry Nephropathy: Review and Future Perspective. Genes 2020, 11, 1091. [CrossRef] [PubMed]

24. Barba-Romero, M.; Pintos-Morell, G. Gender Differences in the Application of Spanish Criteria for Initiation of Enzyme Replacement Therapy for Fabry Disease in the Fabry Outcome Survey. Int. J. Mol. Sci. 2016, 17, 1965. [CrossRef] [PubMed]

25. Veroux, M.; Monte, I.P.; Rodolico, M.S.; Corona, D.; Bella, R.; Basile, A.; Palmucci, S.; Pistorio, M.L.; Lanza, G.; De Pasquale, C.; et al. Screening for Fabry Disease in Kidney Transplant Recipients: Experience of a Multidisciplinary Team. Biomedicines 2020, 8, 396. [CrossRef] [PubMed]

26. Capelli, I.; Aiello, V.; Gasperoni, L.; Comai, G.; Corradetti, V.; Ravaioli, M.; Biagini, E.; Graziano, C.; La Manna, G. Kidney Transplant in Fabry Disease: A Revision of the Literature. Medicina 2020, 56, 284. [CrossRef]

27. Ravarotto, V.; Simioni, F.; Carraro, G.; Bertoldi, G.; Pagnin, E.; Calò, L.A. Oxidative Stress and Cardiovascular-Renal Damage in Fabry Disease: Is There Room for a Pathophysiological Involvement? J. Clin. Med. 2018, 7, 409. [CrossRef]

28. Hughes, D.A.; Aguiar, P.; Deegan, P.B.; Ezgu, F.; Frustaci, A.; Lidove, O.; Linhart, A.; Lubanda, J.C.; Moon, J.C.; Nicholls, K.; et al. Early indicators of disease progression in Fabry disease that may indicate the need for disease-specific treatment initiation: Findings from the opinion-based PREDICT-FD modified Delphi consensus initiative. BMJ Open 2020, 10, e035182. [CrossRef]

29. Pisani, A.; Visciano, B.; Roux, G.D.; Sabbatini, M.; Porto, C.; Parenti, G.; Imbriaco, M. Enzyme replacement therapy in patients with Fabry disease: State of the art and review of the literature. Mol. Genet. Metab. 2012, 107, 267-275. [CrossRef]

30. Lambert, J.R.A.; Howe, S.J.; Rahim, A.A.; Burke, D.G.; Heales, S.J.R. Inhibition of Mitochondrial Complex I Impairs Release of $\alpha$-Galactosidase by Jurkat Cells. Int. J. Mol. Sci. 2019, 20, 4349. [CrossRef]

31. Duro, G.; Zizzo, C.; Cammarata, G.; Burlina, A.; Burlina, A.; Polo, G.; Scalia, S.; Oliveri, R.; Sciarrino, S.; Francofonte, D.; et al. Mutations in the GLA Gene and LysoGb3: Is It Really Anderson-Fabry Disease? Int. J. Mol. Sci. 2018, 19, 3726. [CrossRef] [PubMed]

32. Bernardini, A.; Camporeale, A.; Pieroni, M.; Pieruzzi, F.; Figliozzi, S.; Lusardi, P.; Spada, M.; Mignani, R.; Burlina, A.; Carubbi, F.; et al. Atrial Dysfunction Assessed by Cardiac Magnetic Resonance as an Early Marker of Fabry Cardiomyopathy. JACC Cardiovasc. Imaging 2020, 13, 2262-2264. [CrossRef] [PubMed]

33. Arends, M.; Körver, S.; Hughes, D.A.; Mehta, A.; Hollak, C.E.M.; Biegstraaten, M. Phenotype, disease severity and pain are major determinants of quality of life in Fabry disease: Results from a large multicenter cohort study. J. Inherit. Metab. Dis. 2018, 41, 141-149. [CrossRef] [PubMed]

34. Branton, M.H.; Schiffmann, R.; Sabnis, S.G.; Murray, G.J.; Quirk, J.M.; Altarescu, G.; Goldfarb, L.; Brady, R.O.; Balow, J.E.; Austin Iii, H.A.; et al. Natural history of Fabry renal disease: Influence of alpha-galactosidase A activity and genetic mutations on clinical course. Medicine 2002, 81, 122-138. [CrossRef] [PubMed]

35. Pisani, A.; Visciano, B.; Imbriaco, M.; Di Nuzzi, A.; Mancini, A.; Marchetiello, C.; Riccio, E. The kidney in Fabry's disease. Clin. Genet. 2014, 86, 301-309. [CrossRef] [PubMed]

36. Desnick, R.J.; Simmons, R.L.; Allen, K.Y.; Woods, J.E.; Anderson, C.F.; Najarian, J.S.; Krivit, W. Correction of enzymatic deficiencies by renal transplantation: Fabry's disease. Surgery 1972, 72, 203-211. [PubMed]

37. Philippart, M.; Franklin, S.S.; Gordon, A. Reversal of an inborn sphingolipidosis (Fabry's disease) by kidney transplantation. Ann. Intern. Med. 1972, 77, 195-200. [CrossRef]

38. Philippart, M.; Franklin, S.S.; Leeber, D.A.; Hull, A.R.; Peters, P.C. Kidney transplantation in Fabry's disease. N. Engl. J. Med. 1973, 289, 270-271. [CrossRef]

39. Krivit, W.; Bernlohr, R.W.; Desnick, R.J. Enzyme replacement in genetic disease. Prospectus. Birth Defects Orig. Artic. Ser. 1973, 9 , 232-233.

40. Peces, R. Is there true recurrence of Fabry's disease in the transplanted kidney? Nephrol. Dial. Transpl. 1996, 11, 561. [CrossRef]

41. Mosnier, J.F.; Degott, C.; Bedrossian, J.; Molas, G.; Degos, F.; Pruna, A.; Potet, F. Recurrence of Fabry's disease in a renal allograft eleven years after successful renal transplantation. Transplantation 1991, 51, 759-762. [CrossRef] [PubMed] 
42. Moher, D.; Liberati, A.; Tetzlaff, J.; Altman, D.G. Preferred reporting items for systematic reviews and meta-analyses: The PRISMA statement. PLoS Med. 2009, 6, e1000097. [CrossRef] [PubMed]

43. DerSimonian, R.; Laird, N. Meta-analysis in clinical trials. Control. Clin. Trials 1986, 7, 177-188. [CrossRef]

44. Higgins, J.P.; Thompson, S.G.; Deeks, J.J.; Altman, D.G. Measuring inconsistency in meta-analyses. BMJ 2003, 327, 557-560. [CrossRef]

45. Easterbrook, P.J.; Berlin, J.A.; Gopalan, R.; Matthews, D.R. Publication bias in clinical research. Lancet 1991, 337, 867-872. [CrossRef]

46. Barnes, B.A.; Bergan, J.J.; Braun, W.E. Renal transplantation in congenital and metabolic diseases. A report from the ASC/NIH renal transplant registry. J. Am. Med Assoc. 1975, 232, 148-153. [CrossRef]

47. Donati, D.; Novario, R.; Gastaldi, L. Natural history and treatment of uremia secondary to Fabry's disease: An European experience. Nephron 1987, 46, 353-359. [CrossRef]

48. Tsakiris, D.; Simpson, H.K.L.; Jones, E.H.P.; Briggs, J.D.; Elinder, C.G.; Mendel, S.; Piccoli, G.; Dos Santos, J.P.; Tognoni, C.; Vanrenterghem, Y.; et al. Rare diseases in renal replacement therapy in the ERA-EDTA Registry. Nephrol. Dial. Transpl. 1996, 11, 4-20. [CrossRef]

49. Mazzarella, V.; Splendiani, G.; Tozzo, C.; Tisone, G.; Pisani, F.; Iaria, G.; Casciani, C.U. Renal transplantation in patients with hereditary kidney disease: Our experience. Contrib. Nephrol. 1997, 122, 203-206.

50. Inderbitzin, D.; Avital, I.; Largiadèr, F.; Vogt, B.; Candinas, D. Kidney transplantation improves survival and is indicated in Fabry's disease. Transpl. Proc. 2005, 37, 4211-4214. [CrossRef]

51. Mignani, R.; Feriozzi, S.; Pisani, A.; Cioni, A.; Comotti, C.; Cossu, M.; Foschi, A.; Giudicissi, A.; Gotti, E.; Lozupone, V.A.; et al. Agalsidase therapy in patients with Fabry disease on renal replacement therapy: A nationwide study in Italy. Nephrol. Dial. Transpl. 2008, 23, 1628-1635. [CrossRef] [PubMed]

52. Cybulla, M.; Walter, K.N.; Schwarting, A.; Divito, R.; Feriozzi, S.; Sunder-Plassmann, G. Kidney transplantation in patients with Fabry disease. Transpl. Int. 2009, 22, 475-481. [CrossRef] [PubMed]

53. Shah, T.; Gill, J.; Malhotra, N.; Takemoto, S.K.; Bunnapradist, S. Kidney transplant outcomes in patients with fabry disease. Transplantation 2009, 87, 280-285. [CrossRef] [PubMed]

54. Ojo, A.; Meier-Kriesche, H.U.; Friedman, G.; Hanson, J.; Cibrik, D.; Leichtman, A.; Kaplan, B. Excellent outcome of renal transplantation in patients with Fabry's disease. Transplantation 2000, 69, 2337-2339. [CrossRef]

55. Pineda-Galindo, L.F.; Moranchel-García, L. Beneficial effect of agalsidase beta on long term evolution of patients with Fabry disease and kidney transplant. Mol. Genet. Metab. 2016, 117, S95. [CrossRef]

56. Ersözlü, S.; Huynh-Do, U.; Cippa, P.; Müller, T.; Nowak, A. Long-term outcome of kidney transplantation in Fabry disease. Swiss Med Wkly. 2016, 146, 8S-9S. [CrossRef]

57. Baek, C.H.; Kim, H.; Baek, S.D.; Jang, M.; Kim, W.; Yang, W.S.; Han, D.J.; Park, S.K. Outcomes of living donor kidney transplantation in diabetic patients: Age and sex matched comparison with non-diabetic patients. Korean J. Intern. Med. 2018, 33, 356-366. [CrossRef]

58. Maizel, S.E.; Simmons, R.L.; Kjellstrand, C.; Fryd, D.S. Ten-year experience in renal transplantation for Fabry's disease. Transpl. Proc. 1981, 13, 57-59.

59. Clarke, J.T.R.; Guttmann, R.D.; Wolfe, L.S.; Beaudoin, J.G.; Morehouse, D.D. Enzyme Replacement Therapy by Renal Allotransplantation in Fabry's Disease. N. Engl. J. Med. 1972, 287, 1215-1218. [CrossRef]

60. Wang, A.M.; Desnick, R.J. Structural organization and complete sequence of the human alpha-N-acetylgalactosaminidase gene: Homology with the alpha-galactosidase A gene provides evidence for evolution from a common ancestral gene. Genomics 1991, 10, 133-142. [CrossRef]

61. Wang, A.; Bishop, D.; Desnick, R. Human $\alpha$-N-acetylgalactosaminidase-molecular cloning, nucleotide sequence, and expression of a full-length cDNA: Homology with human $\alpha$-galactosidase a suggests evolution from a common ancestral gene. J. Biol. Chem. 1991, 265, 21859-21866.

62. Touraine, J.L.; Malik, M.C.; Perrot, H.; Maire, I.; Revillard, J.P.; Grosshans, E.; Traeger, J. Fabry's disease: Two patients improved by fetal liver cells (author's transl). Nouv. Presse Med. 1979, 8, 1499-1503. [PubMed]

63. Likhitsup, A.; Helzberg, J.H.; Alba, L.M.; Larkin, M.K.; Cummings, L.S.; Island, E.R.; Lustig, R.M.; Forster, J. Persistent Alphagalactosidase A Deficiency After Simultaneous Liver-kidney Transplantation in a Patient With Fabry Disease. Transplantation 2018, 102, e361. [CrossRef]

64. Mignani, R.; Panichi, V.; Giudicissi, A.; Taccola, D.; Boscaro, F.; Feletti, C.; Prof, G.; Cagnoli, L. Enzyme replacement therapy with agalsidase beta in kidney transplant patients with Fabry disease: A pilot study. Kidney Int. 2004, 65, 1381-1385. [CrossRef] [PubMed]

65. Bénichou, B.; Goyal, S.; Sung, C.; Norfleet, A.M.; O’Brien, F. A retrospective analysis of the potential impact of IgG antibodies to agalsidase beta on efficacy during enzyme replacement therapy for Fabry disease. Mol. Genet. Metab. 2009, 96, 4-12. [CrossRef]

66. Lenders, M.; Stypmann, J.; Duning, T.; Schmitz, B.; Brand, S.M.; Brand, E. Serum-Mediated Inhibition of Enzyme Replacement Therapy in Fabry Disease. J. Am. Soc. Nephrol. 2016, 27, 256-264. [CrossRef]

67. Lenders, M.; Oder, D.; Nowak, A.; Canaan-Kühl, S.; Arash-Kaps, L.; Drechsler, C.; Schmitz, B.; Nordbeck, P.; Hennermann, J.B.; Kampmann, C.; et al. Impact of immunosuppressive therapy on therapy-neutralizing antibodies in transplanted patients with Fabry disease. J. Intern. Med. 2017, 282, 241-253. [CrossRef] [PubMed] 